Supplementary Material for Organic Letters

\title{
Synthesis of Modified DNA by PCR with Alkyne Bearing Purines Followed by a Click Reaction
}

Philipp M. E. Gramlich, Christian T. Wirges, Johannes Gierlich and Thomas Carell*

Section I. Materials

Section II. Synthesis of modified triphosphates

Section III. Primer extension using up to four alkyne-modified triphosphates

Section IV. Polymerase Chain Reaction with $\mathbf{3}$ and $\mathbf{7}$

Section V. UV-VIS and CD spectra of the modified DNA strands

Section VI. Sequence analysis

Section VII. Click reaction on DNA300•2 and DNA300•6 and evaluation of product yield by enzymatic digestion, HPLC and MS/MS

\section{Section I. Materials}

NMR spectra were recorded on a Varian Oxford 200, a Varian XL 400 or a Bruker AMX 600. MALDI mass spectra were recorded on a Bruker Autoflex II. ESI mass spectra were recorded on a Thermo Finnigan LTQ FT.

Template and primers were the same as those mentioned in a previous study. ${ }^{[1]}$ The $294 \mathrm{bp}$ template contains $61.2 \%$ (180 each) $[\mathrm{A}+\mathrm{T}]$ and 38.8\% (114 each) [C+G]. For reasons of simplicity it will be referred to as $300 \mathrm{mer}$. The oligonucleotide primers for PCR were purchased from Metabion and had the following sequence:

primer 1: $\quad$ 5'-TTA ATT GAA TTC GAT TTG GGC CGG ATT TGT TTC-3'

primer 2: $\quad$ 3'-T TTT ATG CTA TCT CTG ATA CCC TTG-3'

Natural triphosphates were obtained from New England Biolabs. KOD XL polymerase was obtained from Novagen, Merck Biosystems and Deep Vent exo Polymerase from New England Biolabs (NEB). Gel loading buffer was obtained from Biorad.

Nuclease P1 (penicillium citrinum) was obtained from Sigma, calf spleen phosphodiesterase II from Calbiochem, alkaline phosphatase (CIP) from New England Biolabs and snake venom phosphodiesterase I (crotalus adamanteus venom) from USB corporation.

PCR reactions were run on an eppendorf realplex ${ }^{4}$ thermocycler.

For primer extension experiments the DNA oligomers were analyzed by $22.5 \%$ TBE-ureaPAGE using the Protean-II-Gel system (Bio-Rad) with a gel length of $20 \mathrm{~cm}$. The gels were run at $40{ }^{\circ} \mathrm{C}$ at a constant current of $30 \mathrm{~mA}$ per gel.

$1 \%$ agarose gels were run with a horizontal cell (Sub-Cell Bio-Rad) at $110 \mathrm{~V}$. The DNA was stained with ethidium bromide.

For analysis of PCR products the DNA was electrophoresed on 5\% denaturing PAGE gels for $30 \mathrm{~min}$ at a constant current of $12 \mathrm{~mA}$ per gel. The 5\% PAGE gels were stained by agitating them in SYBR Green solution (1:10000 dilution) for 20-30 min. The gels were photographed using a Raytest LAS-3000 imager with appropriate cut-off filter (515 nm for SYBR Green). As light source $312 \mathrm{~nm}$ UV or $460 \mathrm{~nm}$ epi-illumination was used. Quantification of gel bands was performed with AIDA image analyzer software.

PCR products used for click reactions were purified on a QIAquick PCR purification kit (Qiagen). DNA extraction from gels was done with a Qiagen gel extraction kit.

Sequence analysis was performed by GATC Biotech. 
UV-VIS spectra were recorded in $10 \mathrm{mM}$ Tris/ $\mathrm{HCl}(\mathrm{pH}: 8.4)$ on a Varian Cary 100 Bio spectrometer at $25{ }^{\circ} \mathrm{C}$ using a $100 \mu \mathrm{L}$ quartz cuvette. The OD $(260 \mathrm{~nm})$ of the DNA solution was adjusted to a value of about 1.0. From the measured spectrum a blank measurement with $10 \mathrm{mM}$ Tris/HCl was subtracted.

The CD spectra were recorded in $10 \mathrm{mM}$ Tris/HCl (pH: 8.4) on a Jasco J-810 spectrometer at $25{ }^{\circ} \mathrm{C}$. The OD $(260 \mathrm{~nm})$ of the DNA solution was adjusted to a value of about 1.0. The CD spectra were taken from the same sample solutions as the UV-VIS spectra. Before or directly after the measurement a blank measurement with $10 \mathrm{mM}$ Tris/ $\mathrm{HCl}$ was recorded and subtracted from the original spectrum.

\section{Section II. Synthesis of modified triphosphates}

\section{7-Deaza-7-(octa-1,7-diynyl)-2’-deoxyadenosine 2}

To a degassed solution of 7-deaza-7-iodo-2'-deoxyadenosine $\mathbf{1}^{[2]}(285 \mathrm{mg}, 0.758 \mathrm{mmol})$ and CuI (29 mg, $0.152 \mathrm{mmol}$ ) in DMF (3 mL) was added dropwise over $15 \mathrm{~min}$ a degassed mixture of 1,7-octadiyne ( $805 \mathrm{mg}, 7.58 \mathrm{mmol})$ and Hünig base $(197 \mathrm{mg}, 1.52 \mathrm{mmol})$ in DMF $(1 \mathrm{~mL})$. Then, $\mathrm{Pd}\left(\mathrm{PPh}_{3}\right)_{4}$ was added and the mixture was stirred at room temperature for $4 \mathrm{~h}$. The mixture was concentrated in vacuo and chromatographed on silica $\left(\mathrm{SiO}_{2}, \mathrm{CHCl}_{3}: \mathrm{MeOH}\right.$ $40: 1 \rightarrow 25: 1$ ) to yield the product as a complex with Hünig base. The amine was removed by dissolving the mixture in methanol $(2 \mathrm{~mL})$ and adding water $(20 \mathrm{~mL})$ to precipitate the product. The suspension was then lyophilized and finally dried in high vacuum to yield the pure product as a light yellow powder $(225 \mathrm{mg}, 0.63 \mathrm{mmol}, 84 \%)$.

$\mathrm{R}_{\mathrm{f}}\left(\mathrm{CHCl}_{3} / \mathrm{MeOH}\right.$ 6:1): 0.3. ${ }^{1} \mathrm{H}$ NMR (DMSO-d6, $\left.400 \mathrm{MHz}\right): \delta=1.60-1.65(\mathrm{~m}, 4 \mathrm{H}$, $\left.\mathrm{CH}_{2}\left(\mathrm{CH}_{2}\right)_{2} \mathrm{CH}_{2}\right), 2.15-2.25$ (m, 4H, $\left.\mathrm{C}_{2} \cdot \mathrm{H}, \mathrm{H}_{2} \mathrm{CCC}-\mathrm{Si}\right), 2.45-2.55$ (m, 2H, $\left.\mathrm{H}_{2} \mathrm{CCC}-\mathrm{Ar}\right), 2.77$ (t, $1 \mathrm{H}, J=2.7 \mathrm{~Hz}, \mathrm{HCC}), 3.50-3.60\left(\mathrm{~m}, 2 \mathrm{H}, \mathrm{C}_{5}, \mathrm{H}\right), 3.80-3.85\left(\mathrm{~m}, 1 \mathrm{H}, \mathrm{C}_{4}, \mathrm{H}\right), 4.30-4.35(\mathrm{~m}, 1 \mathrm{H}$, $\left.\mathrm{C}_{3}, \mathrm{H}\right), 5.05\left(\mathrm{t}, 1 \mathrm{H}, J=5.6 \mathrm{~Hz}, \mathrm{C}_{5}, \mathrm{OH}\right), 5.24\left(\mathrm{~d}, 1 \mathrm{H}, J=4.1 \mathrm{~Hz}, \mathrm{C}_{3}, \mathrm{OH}\right), 6.47(\mathrm{dd}, 1 \mathrm{H}$, $\left.J=8.1 \mathrm{~Hz}, J=6.0 \mathrm{~Hz}, \mathrm{C}_{1}, \mathrm{H}\right), 6.65\left(\right.$ br s, $\left.2 \mathrm{H}, \mathrm{NH}_{2}\right), 7.65\left(\mathrm{~s}, 1 \mathrm{H}, \mathrm{C}_{8} \mathrm{H}\right), 8.10\left(\mathrm{~s}, 1 \mathrm{H}, \mathrm{C}_{2} \mathrm{H}\right)$. ${ }^{13} \mathrm{C}$ NMR (DMSO-d6, $\left.100 \mathrm{MHz}\right): \delta=17.2\left(\mathrm{CH}_{2}\right), 18.4\left(\mathrm{CH}_{2}\right), 27.2\left(\mathrm{CH}_{2}\right), 27.3\left(\mathrm{CH}_{2}\right), 39.8$ $\left(\mathrm{CH}_{2}\right), 61.9\left(\mathrm{CH}_{2}\right), 71.0,71.4(\mathrm{CH}), 73.8,83.1(\mathrm{CH}), 84.2,87.5(\mathrm{CH}), 92.2,95.4,102.3,125.5$ $(\mathrm{CH}), 149.0,152.5,157.5$. HRMS (ESI, m/z): calc. for $\mathrm{C}_{19} \mathrm{H}_{23} \mathrm{~N}_{4} \mathrm{O}_{3}{ }^{+}[\mathrm{M}+\mathrm{H}]^{+}: 355.1765$, found: 355.1755 .

\section{7-Deaza-7-(octa-1,7-diynyl)-2’'deoxyadenosine-5'- $O$-triphosphate 3}

Starting material 2 together with 1,8-bis(dimethylamino)naphthalene (proton sponge) was dried overnight under high vacuum. trimethyl phosphate and the mixture of tributylammonium pyrophosphate and tributyl amine were stirred overnight over molecular sieves.

To a cooled solution $\left(0{ }^{\circ} \mathrm{C}\right)$ of $2(20 \mathrm{mg}, 0.056 \mathrm{mmol})$ and proton sponge $(18 \mathrm{mg}$, $0.084 \mathrm{mmol})$ in trimethyl phosphate $(1 \mathrm{~mL})$ was added $\mathrm{POCl}_{3}(6 \mu \mathrm{L}, 0.067 \mathrm{mmol})$ dropwise over $5 \mathrm{~min}$. The reaction mixture was then stirred for $3 \mathrm{~h}$ at $0{ }^{\circ} \mathrm{C}$. A solution of tributylammonium pyrophosphate $(133 \mathrm{mg}, 0.28 \mathrm{mmol})$ in dry DMF $(0.56 \mathrm{~mL})$ was added to the reaction mixture which was stirred for $10 \mathrm{~min}$ followed by quenching with triethylammonium bicarbonate solution $(1.0 \mathrm{M}, 4 \mathrm{~mL}, \mathrm{pH}=8.5)$. The mixture was stirred at room temperature for additional $3 \mathrm{~h}$ and then lyophilized overnight. RP-HPLC purification (gradient of $0 \rightarrow 55 \% \mathrm{~B}$ with $0.1 \mathrm{M}$ triethylammonium acetate in $\mathrm{H}_{2} \mathrm{O}$ as solvent $\mathrm{A}$ and $0.1 \mathrm{M}$ triethylammonium acetate in $\mathrm{H}_{2} \mathrm{O} / \mathrm{MeCN} 4: 1$ as solvent $\mathrm{B}$ over 45 minutes at a flow rate of $5 \mathrm{~mL} / \mathrm{min})$ yielded $3(22.2 \mathrm{~min}, 11.0 \mu \mathrm{mol}, 20 \%)$ as the triethylammonium salt. The 
triphosphate was dissolved in doubly distilled, sterile water, and its molar concentration was determined by measuring its UV absorption.

${ }^{31} \mathrm{P}$ NMR $\left(\mathrm{D}_{2} \mathrm{O}, 81 \mathrm{MHz}\right): \delta=-21.9(\mathrm{t}, 1 \mathrm{P}, J=19 \mathrm{~Hz}, \beta-\mathrm{P}),-10.1(\mathrm{~d}, 1 \mathrm{P}, J=19 \mathrm{~Hz}, \alpha-\mathrm{P}),-9.5$ $(\mathrm{d}, 1 \mathrm{P}, J=20 \mathrm{~Hz}, \gamma-\mathrm{P}) \mathrm{ppm}$. HRMS (ESI, m/z): calc. for $\mathrm{C}_{19} \mathrm{H}_{24} \mathrm{~N}_{4} \mathrm{O}_{12} \mathrm{P}_{3}^{-}$[M-H] $]^{-}$593.0609, found: 593.0602 .

\section{7-Deaza-[7-(7-trimethylsilyl-octa-1,7-diynyl)]-3',5'-O-di-p-toluoyl-2'-deoxyguanosine 5}

To a thoroughly degassed solution of 4 (130 mg, $0.207 \mathrm{mmol}), \mathrm{PdCl}_{2}\left(\mathrm{PPh}_{3}\right)_{4}(29.0 \mathrm{mg}$, $0.041 \mathrm{mmol})$ and $\mathrm{CuI}(15.7 \mathrm{mg}, 0.082 \mathrm{mmol})$ in anhydrous DMF $(0.7 \mathrm{~mL})$ was added degassed Hünig base $(180 \mu \mathrm{L}, 1.0 \mathrm{mmol})$ in DMF $(0.4 \mathrm{~mL})$ and the reaction mixture was degassed again. A degassed solution of trimethylsilyl-1,7-octadiyne (92 $\mu \mathrm{L}, 0.4 \mathrm{mmol})$ in DMF $(0.3 \mathrm{~mL})$ was added to the reaction mixture over 20 minutes. After complete addition, the reaction mixture was stirred at room temperature overnight. The solvent was removed in vacuo and the residue directly applied to a flash column chromatography $\left(\mathrm{SiO}_{2}\right.$, $\left.\mathrm{CH}_{2} \mathrm{Cl}_{2} / \mathrm{MeOH} 20: 1\right)$. The product was obtained as a pale yellow powder (107 mg, $0.158 \mathrm{mmol}, 76 \%)$.

$\mathrm{R}_{\mathrm{f}}\left(\mathrm{CHCl}_{3} / \mathrm{MeOH} 10: 1\right): 0.45 .{ }^{1} \mathrm{H}$ NMR $\left(\mathrm{CDCl}_{3}, 600 \mathrm{MHz}\right): \delta 0.13\left(\mathrm{~s}, 9 \mathrm{H}, \mathrm{H}_{3} \mathrm{C}-\mathrm{Si}\right), 1.63-1.73$ (m, 4H, $\mathrm{CH}_{2}\left(\mathrm{CH}_{2}\right)_{2} \mathrm{CH}_{2}$ ), 2.25 (t, $2 \mathrm{H}, J=6.9 \mathrm{~Hz}, \mathrm{H}_{2} \mathrm{C}-\mathrm{CC}-\mathrm{Si}$ ), 2,41 (s, 3H, $\mathrm{H}_{3} \mathrm{C}-\mathrm{Ar}$ ), 2,44 (s, $3 \mathrm{H}, \mathrm{H}_{3} \mathrm{C}-\mathrm{Ar}$ ), 2.45 (t, $2 \mathrm{H}, J=6.6 \mathrm{~Hz}, \mathrm{H}_{2} \mathrm{C}-\mathrm{CC}-\mathrm{Ar}$ ), 2.62 (ddd, $1 \mathrm{H}, J=2.1 \mathrm{~Hz}, J=5.8 \mathrm{~Hz}$, $\left.J=14.1 \mathrm{~Hz}, \mathrm{C}_{2} \cdot \mathrm{H}\right), 2.73-2.79\left(\mathrm{~m}, 1 \mathrm{H}, \mathrm{C}_{2} \cdot \mathrm{H}\right), 4.53-4.56\left(\mathrm{~m}, 1 \mathrm{H}, \mathrm{C}_{4} \cdot \mathrm{H}\right), 4.60(\mathrm{dd}, 1 \mathrm{H}$, $\left.J=4.3 \mathrm{~Hz}, J=11.8 \mathrm{~Hz}, \mathrm{C}_{5} \cdot \mathrm{H}\right), 4.69\left(\mathrm{dd}, 1 \mathrm{H}, J=4.6 \mathrm{~Hz}, J=11.8 \mathrm{~Hz}, \mathrm{C}_{5} \cdot \mathrm{H}\right), 5.67-5.70(\mathrm{~m}$, $\left.1 \mathrm{H}, \mathrm{C}_{3} \cdot \mathrm{H}\right), 5.97\left(\mathrm{sbr}, 2 \mathrm{H}, \mathrm{NH}_{2}\right), 6.48\left(\mathrm{dd}, 1 \mathrm{H}, J=6.1 \mathrm{~Hz}, J=8.2 \mathrm{~Hz}, \mathrm{C}_{1} \cdot \mathrm{H}\right), 6.94(\mathrm{~s}, 1 \mathrm{H}$, $\left.\mathrm{C}_{8} \mathrm{H}\right), 7.25\left(\mathrm{~d}, 2 \mathrm{H}, J=7.8 \mathrm{~Hz}, \mathrm{CH}_{\mathrm{Ar}}\right), 7.27\left(\mathrm{~d}, 2 \mathrm{H}, J=7.8 \mathrm{~Hz}, \mathrm{CH}_{\mathrm{Ar}}\right), 7.94(\mathrm{~d}, 2 \mathrm{H}, J=8.4 \mathrm{~Hz}$, $\left.\mathrm{CH}_{\mathrm{Ar}}\right), 7.96\left(\mathrm{~d}, 2 \mathrm{H}, J=8.4 \mathrm{~Hz}, \mathrm{CH}_{\mathrm{Ar}}\right), 11.17(\mathrm{sbr}, 1 \mathrm{H}, \mathrm{NH}) .{ }^{13} \mathrm{C} \mathrm{NMR}\left(\mathrm{CDCl}_{3}, 150 \mathrm{MHz}\right): 0.2$ $\left(\mathrm{CH}_{3}\right), 19.4\left(\mathrm{CH}_{2}\right), 21.7\left(\mathrm{CH}_{3}\right), 21.7\left(\mathrm{CH}_{3}\right), 27.7\left(\mathrm{CH}_{2}\right), 27.9\left(\mathrm{CH}_{2}\right), 37.5\left(\mathrm{CH}_{2}\right), 64.2\left(\mathrm{CH}_{2}\right)$, 73.8, 75.1 (CH), $81.9(\mathrm{CH}), 83.7(\mathrm{CH}), 84.8,90.6,100.5,100.6,107.1,121.6(\mathrm{CH}), 126.5$, 126.8, $129.2(\mathrm{CH}), 129.2(\mathrm{CH}), 129.7(\mathrm{CH}), 129.8(\mathrm{CH}), 143.9,144.3,151.1,152.9,160.1$, 165.9, 166.3. HRMS (ESI, m/z): calc. for $\mathrm{C}_{38} \mathrm{H}_{43} \mathrm{~N}_{4} \mathrm{O}_{6} \mathrm{Si}^{+}[\mathrm{M}+\mathrm{H}]^{+}:$679.2952, found: 679.2962 .

\section{7-Deaza-7-(octa-1,7-diynyl)-2'-deoxyguanosine 6}

5 (30.0 mg, $0.044 \mathrm{mmol})$ was dissolved in dry methanol $(10 \mathrm{~mL})$ saturated with ammonia. The solution was heated in a pressure vessel $\left(140{ }^{\circ} \mathrm{C}\right)$ for $2 \mathrm{~h}$. The solvent was removed in vacuo. The product $(11.0 \mathrm{mg}, 0.027 \mathrm{mmol}, 67 \%)$ was obtained by flash column chromatography $\left(\mathrm{SiO}_{2}, \mathrm{DCM} / \mathrm{MeOH} 9: 1\right)$ as a light brown solid.

$\mathrm{R}_{\mathrm{f}}\left(\mathrm{DCM} / \mathrm{MeOH}\right.$ 9:1): 0.16. ${ }^{1} \mathrm{H}$ NMR $\left(\mathrm{CD}_{3} \mathrm{OD}, 400 \mathrm{MHz}\right): \delta=1.63-1.74(\mathrm{~m}, 4 \mathrm{H}$, $\left.\mathrm{CH}_{2}\left(\mathrm{CH}_{2}\right)_{2} \mathrm{CH}_{2}\right), 2.19$ (t, $\left.1 \mathrm{H}, J=2.8 \mathrm{~Hz}, \mathrm{HCC}\right), 2.20-2.27\left(\mathrm{~m}, 3 \mathrm{H}, \mathrm{H}_{2} \mathrm{CCC}-\mathrm{H}, \mathrm{C}_{2} \mathrm{H}\right), 2.42(\mathrm{t}$, $2 \mathrm{H}, J=6.6 \mathrm{~Hz}, \mathrm{H}_{2} \mathrm{CCC}-\mathrm{Ar}$ ), 2.49 (ddd, $\left.1 \mathrm{H}, J=6.1 \mathrm{~Hz}, J=8.0 \mathrm{~Hz}, J=13.8 \mathrm{~Hz}, \mathrm{C}_{2} \cdot \mathrm{H}\right), 3.66-$ $3.73\left(\mathrm{~m}, 2 \mathrm{H}, \mathrm{C}_{5} \cdot \mathrm{H}\right), 3.92\left(\mathrm{dt}, 1 \mathrm{H}, J=2.8 \mathrm{~Hz}, J=4.0 \mathrm{~Hz}, \mathrm{C}_{4} \cdot \mathrm{H}\right), 4.45(\mathrm{td}, 1 \mathrm{H}, J=2.8 \mathrm{~Hz}$, $\left.J=5.9, \mathrm{C}_{3} \mathrm{H}\right), 6.35\left(\mathrm{dd}, 1 \mathrm{H}, J=6.1 \mathrm{~Hz}, J=8.0 \mathrm{~Hz}, \mathrm{C}_{1} \cdot \mathrm{H}\right) .7 .08\left(\mathrm{~s}, 1 \mathrm{H}, \mathrm{C}_{8} \mathrm{H}\right) \mathrm{ppm} .{ }^{13} \mathrm{C} \mathrm{NMR}$ $\left(\mathrm{CD}_{3} \mathrm{OD}, 100 \mathrm{MHz}\right): \delta=18.6\left(\mathrm{CH}_{2}\right), 19.9\left(\mathrm{CH}_{2}\right), 28.9\left(\mathrm{CH}_{2}\right), 29.0\left(\mathrm{CH}_{2}\right), 41.3\left(\mathrm{CH}_{2}\right), 63.7$ $\left(\mathrm{CH}_{2}\right), 69.6,72.9,73.6,74.7,84.9,85.4,88.7,91.3,101.8,123.3(\mathrm{CH}), 151.9,154.3$, 161.3 ppm. HRMS (ESI, m/z): calc. for $\mathrm{C}_{19} \mathrm{H}_{21} \mathrm{~N}_{4} \mathrm{O}_{4}{ }^{-}[\mathrm{M}-\mathrm{H}]: 369.1563$, found: 369.1573 . 


\section{7-Deaza-7-(octa-1,7-diynyl)-2'-deoxyguanosine-5'-O-triphosphate 7}

To a cooled solution $\left(0^{\circ} \mathrm{C}\right)$ of $\mathbf{6}(32 \mathrm{mg}, \quad 0.086$ mmol. $)$ and 1,8bis(dimethylamino)naphthalene (proton sponge, $0.068 \mathrm{~g}, 0.316 \mathrm{mmol}$ ) in trimethyl phosphate $(0.8 \mathrm{~mL})$ was added $\mathrm{POCl}_{3}(9.5 \mu \mathrm{L}, 0.103 \mathrm{mmol})$ dropwise over 5 minutes under a nitrogen atmosphere. The reaction mixture was stirred for $3 \mathrm{~h}$ at $0{ }^{\circ} \mathrm{C}$. A solution of tributylammonium pyrophosphate $(0.086 \mathrm{~g}, 0.16 \mathrm{mmol})$ in dry DMF $(1.0 \mathrm{~mL})$ and tributyl amine $(136 \mu \mathrm{L})$ was added to the reaction mixture and stirred for 35 minutes followed by quenching with triethylammonium bicarbonate $(1.0 \mathrm{M}, 12 \mathrm{~mL}, \mathrm{pH}=8.5)$. The reaction mixture was stirred for $2 \mathrm{~h}$ and lyophilized overnight. RP-HPLC purification (gradient of $0 \rightarrow 40 \% \mathrm{~B}$ with $0.1 \mathrm{M}$ triethylammonium acetate in $\mathrm{H}_{2} \mathrm{O}$ as solvent $\mathrm{A}$ and $0.1 \mathrm{M}$ triethylammonium acetate in $\mathrm{H}_{2} \mathrm{O} / \mathrm{MeCN} 4: 1$ as solvent $\mathrm{B}$ over 45 minutes at a flow rate of $15 \mathrm{~mL} / \mathrm{min}$ ) yielded 7 (22.2 min, $1.7 \mu \mathrm{mol}, 2 \%)$ as the triethylammonium salt. The triphosphate was dissolved in doubly distilled, sterile water, and its molar concentration was determined by measuring its UV absorption.

${ }^{31} \mathrm{P}$ NMR $\left(\mathrm{D}_{2} \mathrm{O}, 81 \mathrm{MHz}\right): \delta=-22.3(\mathrm{t}, 1 \mathrm{P}, J=20 \mathrm{~Hz}, \beta-\mathrm{P}),-10.3(\mathrm{~d}, 1 \mathrm{P}, J=20 \mathrm{~Hz}, \alpha-\mathrm{P}),-9.9$ $(\mathrm{d}, 1 \mathrm{P}, J=20 \mathrm{~Hz}, \gamma-\mathrm{P}) \mathrm{ppm}$. MALDI-TOF (HPA matrix, negative mode, m/z): $608.9[\mathrm{M}-\mathrm{H}]^{-}$.

Section III. Primer extension using up to four alkyne-modified triphosphates

$\begin{array}{lr}\text { Pr1 } & \text { 3’-CA TGG GCC AAG CTT CTT CGG-5' } \\ \text { T1 } & \text { 5'-TCG TCA GTC GGT ACC CGG TTC GAA GAA GCC-3' } \\ \text { T2 } & \text { 5'-TCG TAA GTC GGT ACC CGG TTC GAA GAA GCC-3' }\end{array}$

For primer extension experiments an assay developed by Held et al. was used. ${ }^{[3]}$ The primer extensions were run in a total volume of $20 \mu \mathrm{L}$ with the final concentrations of $750 \mathrm{nM}$ primer, $900 \mathrm{nM}$ template, $200 \mu \mathrm{M}$ dNTPs, 1x KOD XL PCR buffer and 1 unit polymerase. The primer and template were hybridized by heating to $95{ }^{\circ} \mathrm{C}$ and cooling to $4{ }^{\circ} \mathrm{C}$ prior to the reaction. The extension was started by adding the polymerase and incubating the entire mixture at $40{ }^{\circ} \mathrm{C}$ (temperature increment $+1{ }^{\circ} \mathrm{C}$ per $120 \mathrm{~s}$ up to $74{ }^{\circ} \mathrm{C}$ ). The extension was then quenched with $2 \mu \mathrm{L}$ EDTA $(0.1 \mathrm{M}, \mathrm{pH}=7.5)$ and $10 \mu \mathrm{L}$ gel loading buffer. From that solution $10 \mu \mathrm{L}$ were run on a $20 \%$ PAGE-Gel. 


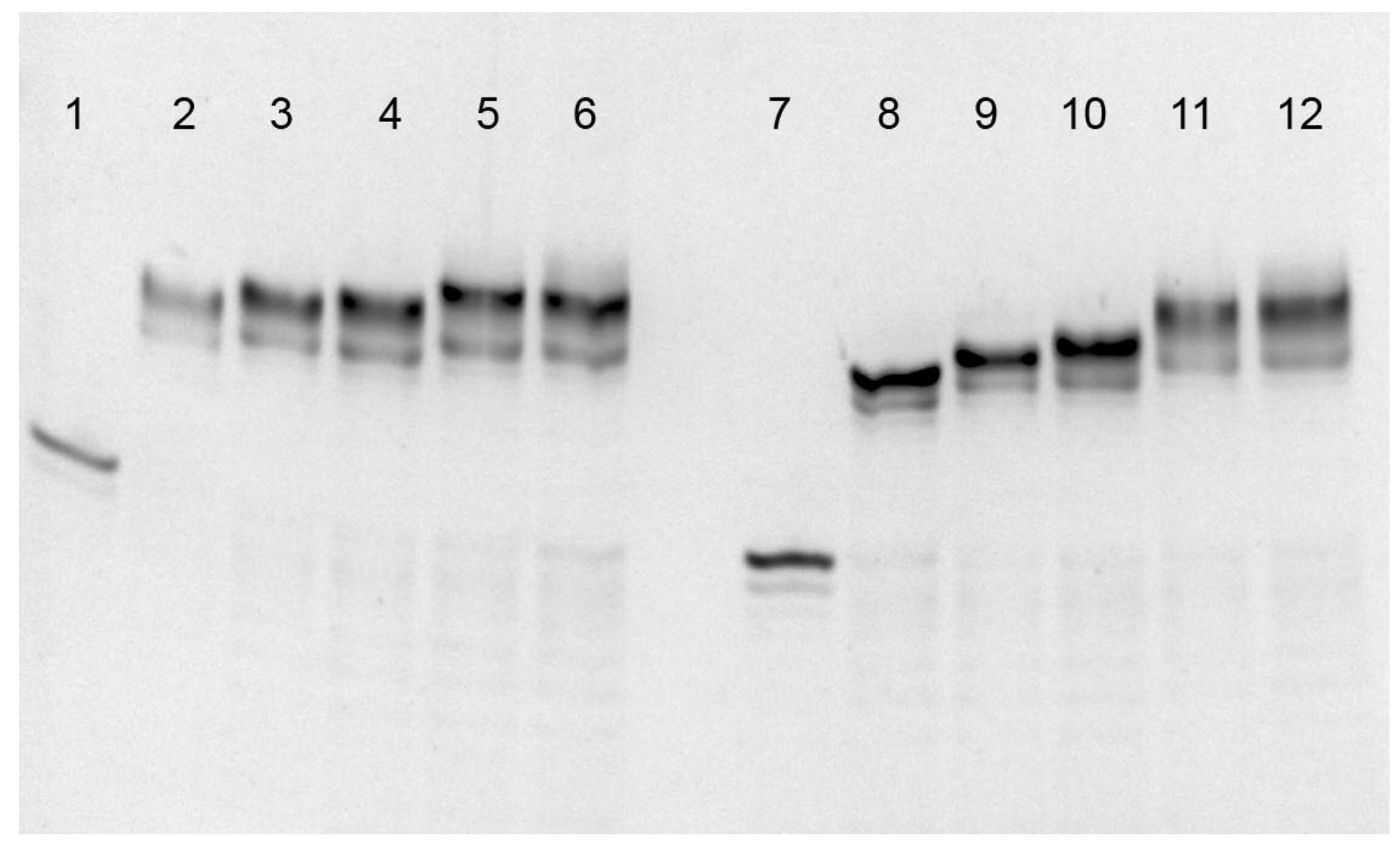

Scheme S1: Primer extension on T1 (lanes 1-6) and T2 (lanes 7-12). Lanes 1 and 7: primers; lanes 2 and 8: primer extension with dNTPs; lanes 3 and 9: 9, dATP, dGTP, dTTP, lanes 4 and 10: 9, 11, dATP, dGTP; lanes 5 and 11: 3, 9, 11, dGTP; lanes 6 and 12: 3, 7, 9, 11.

\section{Section IV. Polymerase Chain Reaction with 3 and 7}

\section{Incorporation of triphosphates 3 or 7 into a PCR amplicon}

A typical PCR reaction in a total volume of $25 \mu \mathrm{L}$ contained $0.4 \mu \mathrm{g}$ template, $0.3 \mu \mathrm{M}$ each of the forward and reverse primers (both fluorescein-labeled for 7, both unlabeled for 3 ), $1 \mathrm{U}$ KOD XL polymerase, 10x polymerase buffer as supplied by the manufacturer $(2.5 \mu \mathrm{L})$ and $200 \mu \mathrm{M}$ of each dNTP (corresponding natural dNTPs substituted by modified triphosphates 3 or 7).

PCR program for amplification of $\mathbf{3}$ :

Hotstart $\left(2 \mathrm{~min}\right.$ at $\left.95^{\circ} \mathrm{C}\right), 9$ cycles of touchdown amplification $\left(15 \mathrm{sec} 95^{\circ} \mathrm{C}, 30 \mathrm{sec} 58{ }^{\circ} \mathrm{C}\right.$ with temperature increment of $-1{ }^{\circ} \mathrm{C} /$ cycle, $45 \mathrm{sec} 72^{\circ} \mathrm{C}$ ), then 30 cyles of amplification $\left(15 \sec 95^{\circ} \mathrm{C}, 30 \sec 57^{\circ} \mathrm{C}, 45 \sec 72^{\circ} \mathrm{C}\right.$ ) followed by a final incubation at $72{ }^{\circ} \mathrm{C}$ for $2 \mathrm{~min}$. PCR program for amplification of 7 :

For amplification hotstart $\left(2 \mathrm{~min}\right.$ at $\left.97.6^{\circ} \mathrm{C}\right)$ was used, followed by 9 cycles of touchdown amplification $\left(30 \mathrm{~s}\right.$ at $97.6{ }^{\circ} \mathrm{C}, 30 \mathrm{~s}$ at $60.7{ }^{\circ} \mathrm{C}$, temperature increment $-1{ }^{\circ} \mathrm{C}$ per cycle, $60 \mathrm{~s}$ at $\left.74{ }^{\circ} \mathrm{C}\right), 30$ cycles amplification $\left(30 \mathrm{~s}\right.$ at $97.6{ }^{\circ} \mathrm{C}, 30 \mathrm{~s}$ at $59.7{ }^{\circ} \mathrm{C}, 60 \mathrm{~s}$ at $\left.74{ }^{\circ} \mathrm{C}\right)$ and a final incubation for $2 \mathrm{~min}$ at $72{ }^{\circ} \mathrm{C}$. 

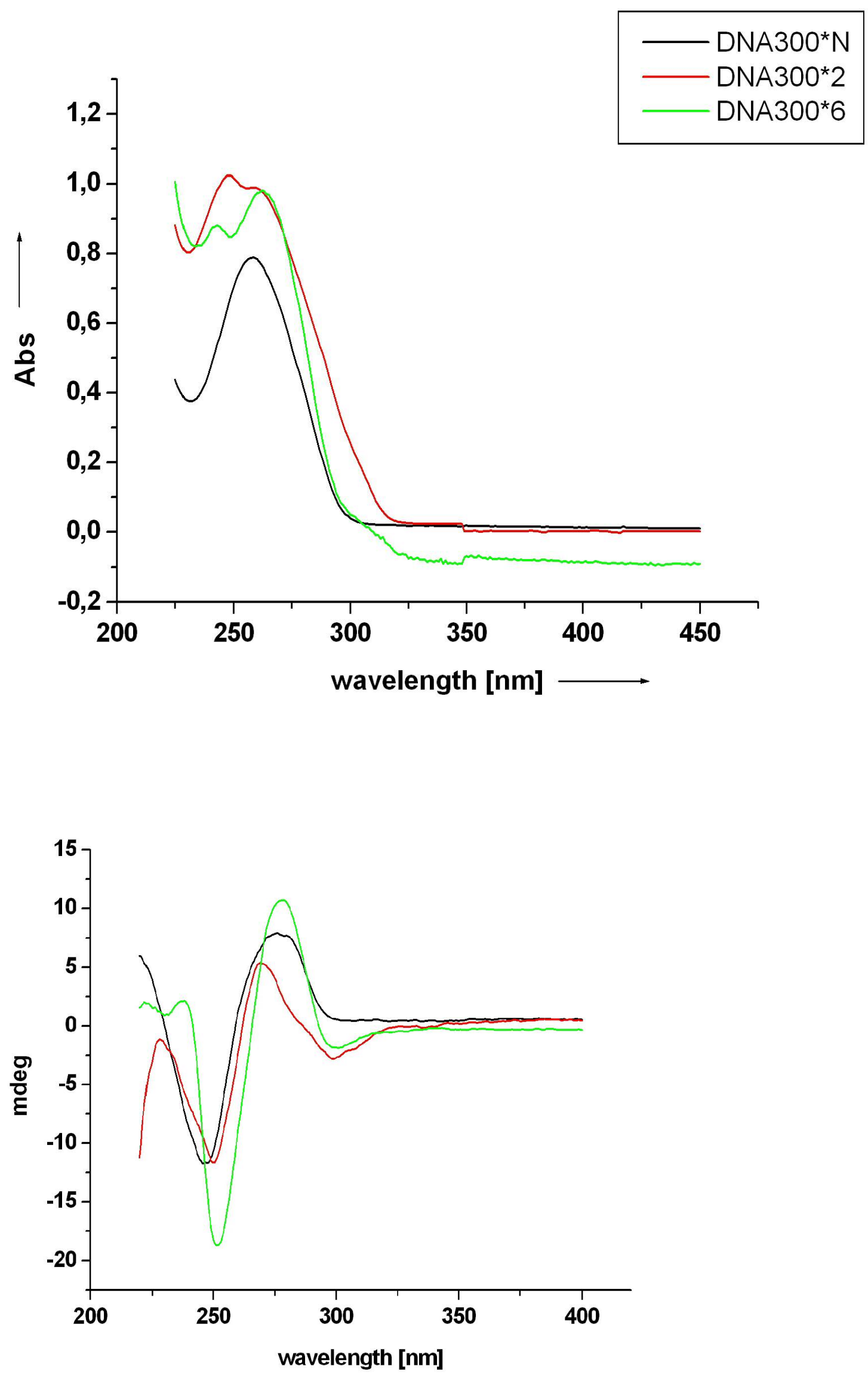

Scheme S2. UV and CD spectra of DNA300•N, DNA300•2 and DNA300•6. 


\section{Section VI. Sequence analysis}

To verify the sequence-fidelity of the PCR-reaction with our modified triphosphates, the alkyne-modified PCR products were first purified by agarose gel electrophoresis followed by isolation of the desired band and gel elution. The pure alkyne-modified DNA was then used as a template in a second PCR reaction, this time with native dNTPs. The unmodified DNA product of this PCR was purified by gel extraction as described above and the sequence analyzed.

PCR conditions for amplification of modified template DNA300•2 with natural dNTPs:

$20 \mathrm{ng}$ of DNA300 2 as template, $0.3 \mu \mathrm{M}$ of both primers, $1 \mathrm{U}$ Deep Vent exo ${ }^{-}$polymerase, 10x Deep Vent exo ${ }^{-}$buffer $(2.5 \mu \mathrm{L})$ and $200 \mu \mathrm{M}$ of each dNTP were mixed to a total volume of $25 \mu \mathrm{L}$ with sterile, doubly distilled water.

PCR program: Hotstart $\left(2 \min\right.$ at $\left.95^{\circ} \mathrm{C}\right), 9$ cycles of touchdown amplification $\left(15 \sec 95^{\circ} \mathrm{C}\right.$, $30 \sec 62{ }^{\circ} \mathrm{C}$ with temperature increment of $-1{ }^{\circ} \mathrm{C} /$ cycle, $45 \mathrm{sec} 72{ }^{\circ} \mathrm{C}$ ), then 30 cyles of amplification $\left(15 \sec 95^{\circ} \mathrm{C}, 30 \sec 59^{\circ} \mathrm{C}, 45 \sec 72^{\circ} \mathrm{C}\right)$ followed by a final incubation at $72{ }^{\circ} \mathrm{C}$ for $2 \mathrm{~min}$.

PCR conditions for amplification of modified template DNA300・7 with natural dNTPs:

$10 \mu \mathrm{g}$ DNA300•6, $0.3 \mathrm{mM}$ each of the forward and reverse primers, $1 \mathrm{U}$ KOD XL or Pwo polymerase, 10x KOD or Deep Vent exo ${ }^{-}$PCR buffer $(2.5 \mu \mathrm{L})$ and $200 \mu \mathrm{M}$ of each dNTP were mixed to a total volume of $25 \mu \mathrm{L}$ with sterile, doubly distilled water.

PCR program: Hotstart $\left(2\right.$ min at $\left.95^{\circ} \mathrm{C}\right)$, followed by 9 cycles of touchdown amplification $\left(15 \mathrm{~s}\right.$ at $95^{\circ} \mathrm{C}, 30 \mathrm{~s}$ at $60.7^{\circ} \mathrm{C}(\mathrm{KOD} \mathrm{XL})$ or $53.2^{\circ} \mathrm{C}$ (Deep Vent exo'), temperature increment $-1{ }^{\circ} \mathrm{C}$ per cycle, $45 \mathrm{~s}$ at $\left.72{ }^{\circ} \mathrm{C}\right), 30$ cycles amplification $\left(15 \mathrm{~s}\right.$ at $95^{\circ} \mathrm{C}, 30 \mathrm{~s}$ at $58.5^{\circ} \mathrm{C}(\mathrm{KOD}$ $\mathrm{XL}$ ) or $50.2{ }^{\circ} \mathrm{C}$ (Deep Vent exo ), $45 \mathrm{~s}$ at $72{ }^{\circ} \mathrm{C}$ ) and a final incubation for $2 \mathrm{~min}$ at $72{ }^{\circ} \mathrm{C}$.

Sequence analysis for retranscription product of DNA300•2 using Deep Vent exo ${ }^{-}$ polymerase: 


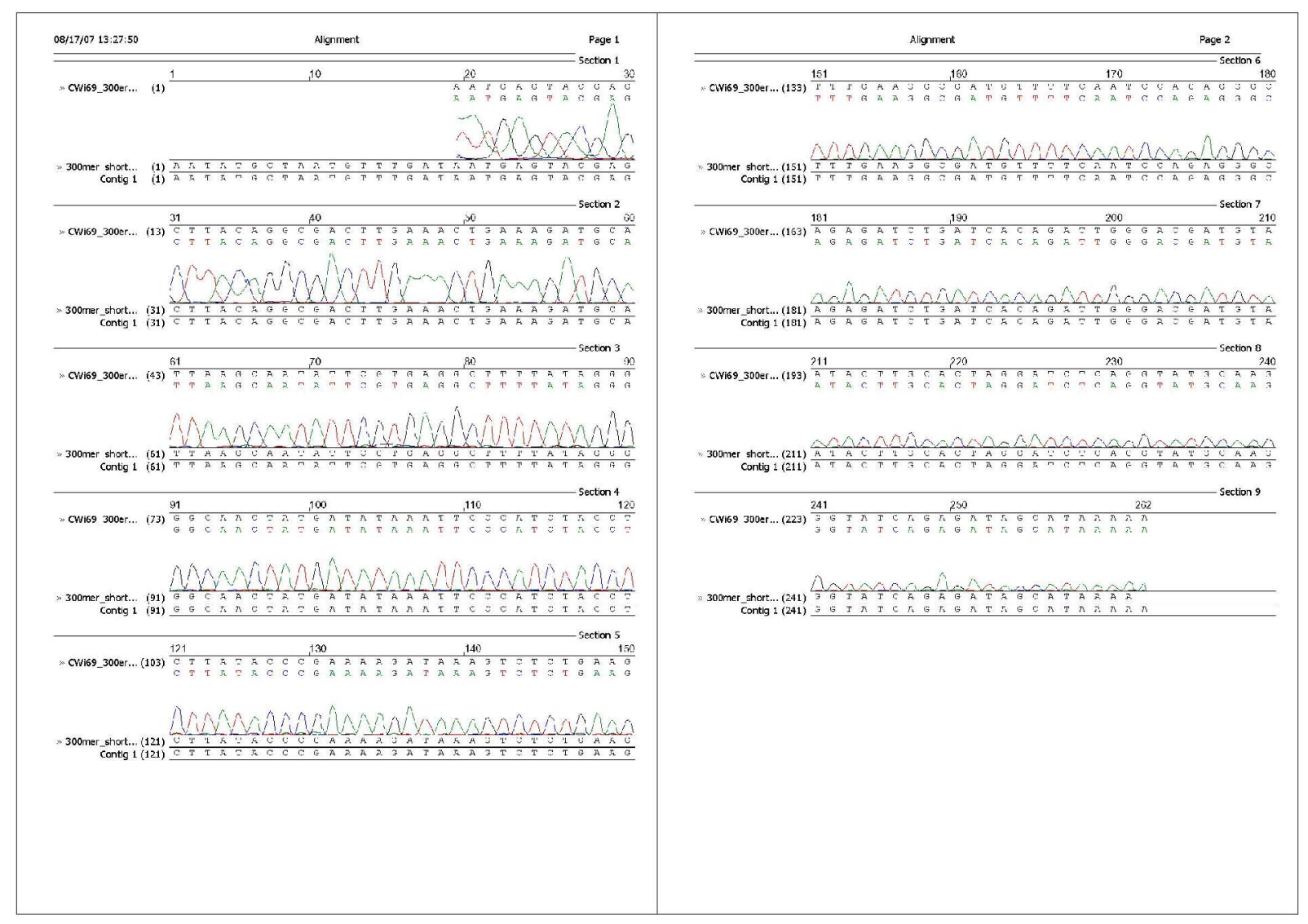


Sequence analysis for retranscription product of DNA300•6 using KOD XL polymerase:

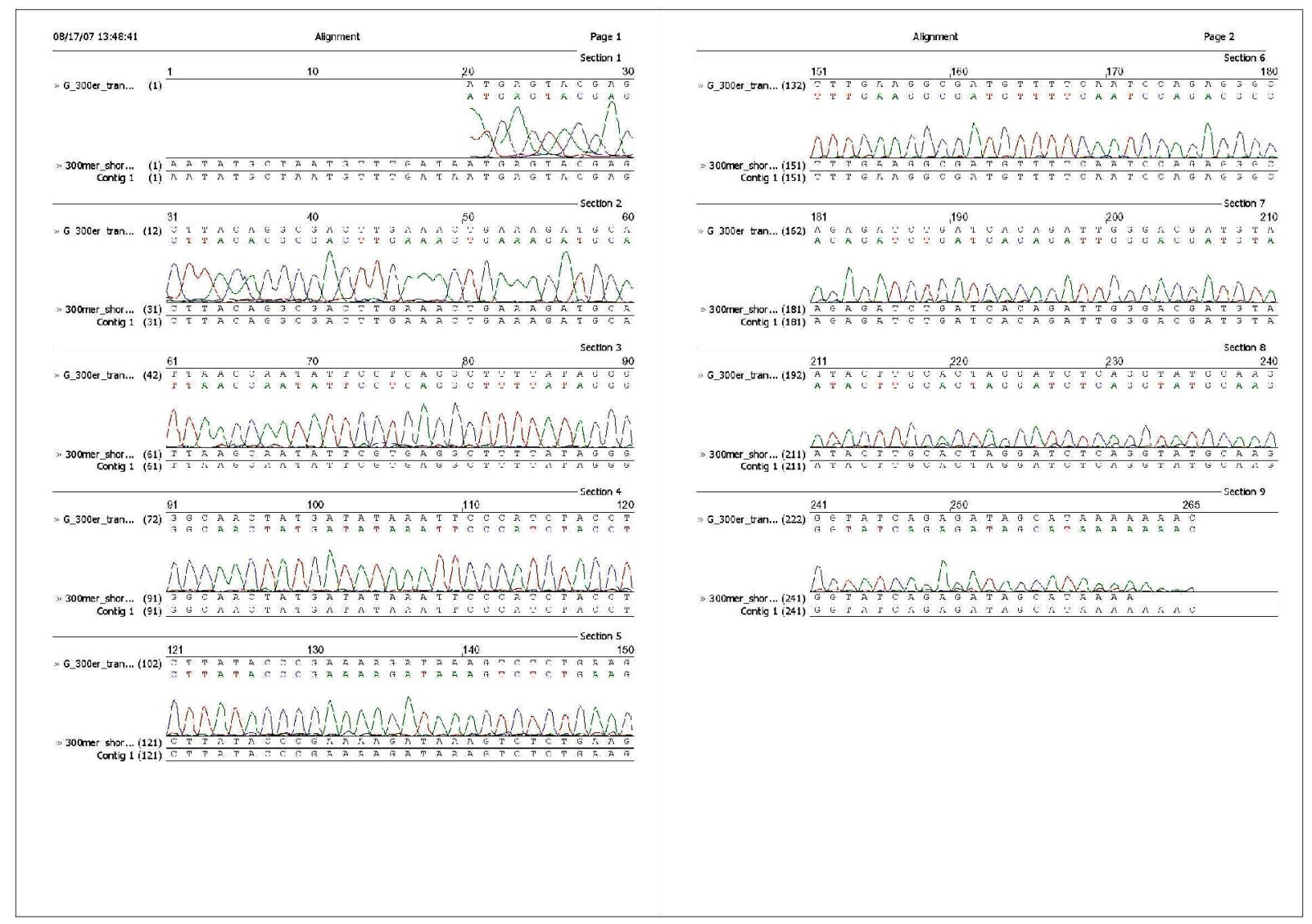


Sequence analysis for retranscription product of DNA300•6 using Deep Vent exo polymerase:

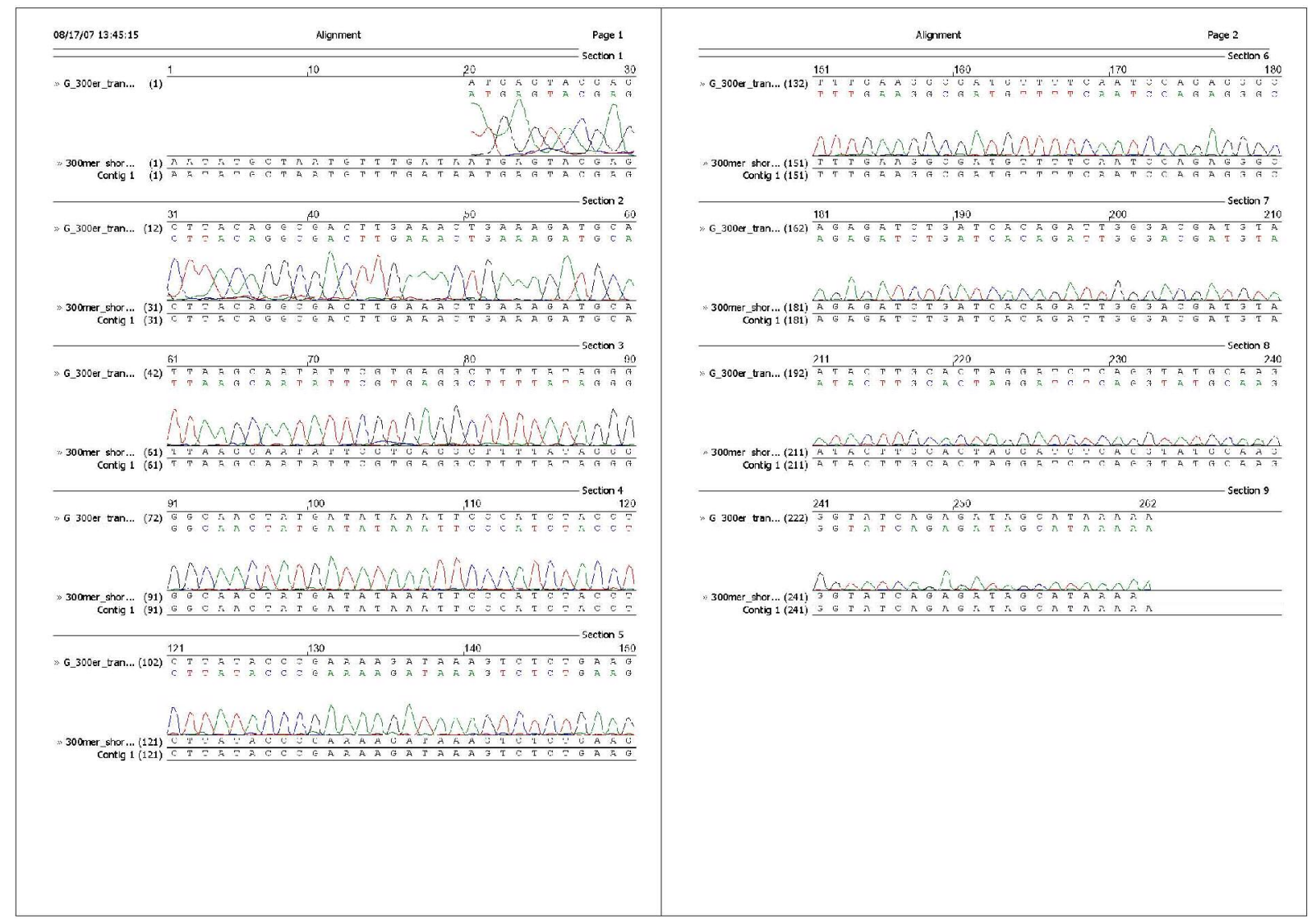

Both sequence analyses show an exact accordance with the original template sequence. This shows that both adenosine triphosphate $\mathbf{3}$ and guanosine triphosphate $\mathbf{7}$ are incorporated into DNA with high sequence-fidelity and be retranscribed by two different polymerases.

\section{Section VII. Click reaction on PCR amplicons and evaluation of product yield by enzymatic digestion, HPLC and MS/MS}

$2 \mu \mathrm{g}$ DNA and $2 \mu \mathrm{mol} 12$ were placed in a $1.5 \mathrm{~mL}$ vial and lyophilized. In a separate vial, $\mathrm{CuBr}$ solution $(10 \mathrm{mM}$ in $\mathrm{DMSO} / \mathrm{tBuOH} 3: 1,5 \mu \mathrm{L})$ and TBTA ligand ${ }^{[4]}$ solution $(10 \mathrm{mM}$ in $\mathrm{DMSO} / \mathrm{tBuOH}$ 3:1, $5 \mu \mathrm{L}$ ) were vortexed and added to the DNA. $10 \mu \mathrm{L} \mathrm{H}_{2} \mathrm{O}$ were added. The solution was shaken at $37^{\circ} \mathrm{C}$ for $2 \mathrm{~h}$ and then lyophilized to dryness. $100 \mu \mathrm{L}$ sodium acetate solution $(0.3 \mathrm{M})$ was added to dissolve the DNA. $1 \mathrm{~mL}$ ethanol was added, the vial was vortexed and placed in a freezer $\left(-20^{\circ} \mathrm{C}\right)$ overnight. After centrifugation $(15 \mathrm{~min}$ at $13000 \mathrm{rpm}$ ) the supernatant was carefully removed from the DNA pellet. $70 \%$ ethanol $\left(-20^{\circ} \mathrm{C}\right)$ was added, the vial was vortexed, centrifuged and the supernatant removed. This washing step was repeated twice. After the last washing step the pellet was left drying on air.

For the enzymatic digest the DNA (about $2 \mu \mathrm{g}$ taken up in $100 \mu \mathrm{L}$ water) was incubated in $10 \mu \mathrm{L}$ buffer A (300 mM ammonium acetate, $100 \mathrm{mM} \mathrm{CaCl}_{2}, 1 \mathrm{mM} \mathrm{ZnSO}_{4}$, pH 5.7) together with 11 units of nuclease $\mathrm{P} 1$ and 0.05 units of calf spleen phosphodiesterase II. The sample was shaken at $37^{\circ} \mathrm{C}$ for $3 \mathrm{~h}$. The digest was completed by adding $12 \mu \mathrm{L}$ buffer B $(500 \mathrm{mM}$ Tris- $\mathrm{HCl}, 1 \mathrm{mM}$ EDTA, pH 8.0), 10 units alkaline phosphatase (CIP) and 0.1 units snake 
venom phosphodiesterase I. The sample was shaken for another $3 \mathrm{~h}$ at $37{ }^{\circ} \mathrm{C}$. For workup the samples were centrifuged (13000 rpm, $5 \mathrm{~min}$ ).

The digest solution was analyzed by HPLC, buffer A: $2 \mathrm{mM} \mathrm{NH} \mathrm{NCOO}_{4} \mathrm{Hn} \mathrm{H}_{2} \mathrm{O}(\mathrm{pH}$ : 5.5); buffer B: 2 mM NH $\mathrm{H}_{4} \mathrm{HCOO}$ in $\mathrm{H}_{2} \mathrm{O}: \mathrm{MeCN}$ 1:4; gradient: $0 \rightarrow 12$ min; $0 \% \rightarrow 3 \% \mathrm{~B} ; 12 \rightarrow$ $60 \mathrm{~min} ; 3 \% \rightarrow 60 \% \mathrm{~B} ; 60 \rightarrow 62 \mathrm{~min} ; 60 \% \rightarrow 100 \% \mathrm{~B} ; 62 \rightarrow 90 \mathrm{~min} ; 100 \% \mathrm{~B} ; 90 \rightarrow 95 \mathrm{~min}$; $100 \% \mathrm{~B} \rightarrow 0 \% \mathrm{~B} ; 95 \rightarrow 130 \mathrm{~min} ; 0 \% \mathrm{~B}$; flow $0.15 \mathrm{~mL} / \mathrm{min})$. The different peaks were assigned by co-injection, UV and FT-ICR-HPLC-MS-MS using the same conditions.

ESI-MS/MS-data of the digest of DNA300•2:

\begin{tabular}{|c|c|c|}
\hline & FTICR-MS & MS/MS \\
\hline $\begin{array}{c}\text { Starting material: nucleoside } \mathbf{2} \\
\text { at } 54.0 \min \left(\mathrm{C}_{19} \mathrm{H}_{22} \mathrm{~N}_{4} \mathrm{O}_{3}\right)\end{array}$ & $\begin{array}{c}{[\mathrm{M}+\mathrm{HCOO}]^{-}: \text {calc. }} \\
399.1674, \text { found } 399.1674\end{array}$ & $\begin{array}{c}\text { [M-H] : calc. } \\
353.2 \text {, found } 353.2\end{array}$ \\
\hline $\begin{array}{l}\text { Click product of nucleoside } 2 \\
\text { at } 39.6 \text { min and } 39.9 \text { min } \\
\qquad\left(\mathrm{C}_{25} \mathrm{H}_{33} \mathrm{~N}_{7} \mathrm{O}_{8}\right)\end{array}$ & $\begin{array}{c}{[\mathrm{M}+\mathrm{HCOO}]^{-}: \text {calc. }} \\
604.2373, \text { found } 604.2371\end{array}$ & $\begin{array}{c}{[\mathrm{M}-\mathrm{H}]^{-} \text {: calc. }} \\
558.2, \text { found } 558.1\end{array}$ \\
\hline
\end{tabular}

ESI-MS/MS-data of the digest of DNA300•6:

\begin{tabular}{c|c|c} 
& FTICR-MS & MS/MS \\
\hline Starting material: nucleoside 6 & {$[\mathrm{M}+\mathrm{HCOO}]^{-}$: calc. } & {$[\mathrm{M}-\mathrm{H}]^{-}:$calc. } \\
at 47.0 min $\left(\mathrm{C}_{19} \mathrm{H}_{22} \mathrm{~N}_{4} \mathrm{O}_{4}\right)$ & 415.1623 , found 415.1623 & 369.2 , found 369.2 \\
\hline Click product of nucleoside 6 & {$[\mathrm{M}-\mathrm{H}]^{-}$: calc. 574.2267, } & - \\
at 36.4 min and 36.8 min & found 574.2265 & \\
$\left(\mathrm{C}_{25} \mathrm{H}_{33} \mathrm{~N}_{7} \mathrm{O}_{9}\right)$ &
\end{tabular}



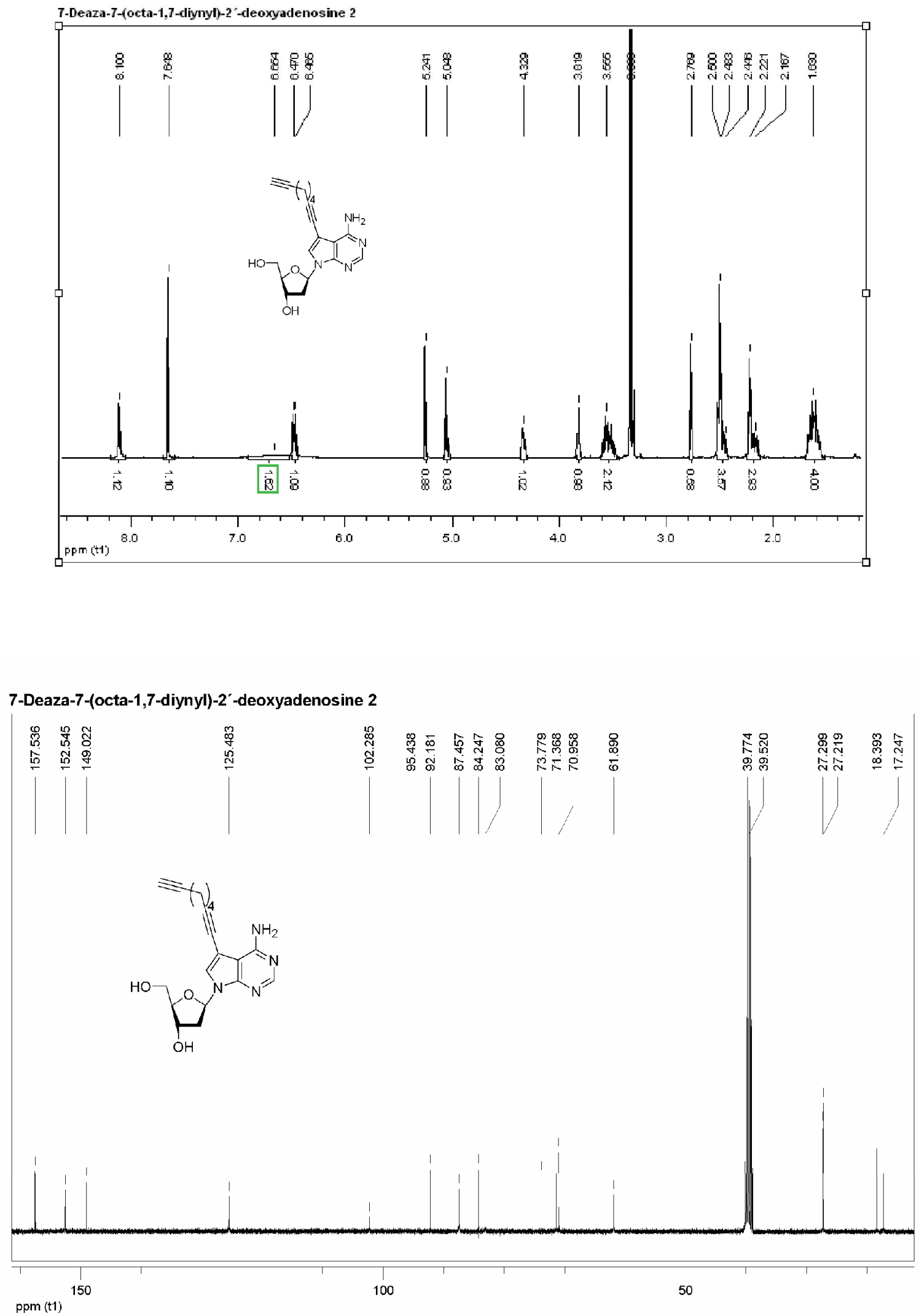
7-Deaza-7-(octa-1,7-diynyl)-2'-deoxyadenosine-5'-0-triphosphate 3

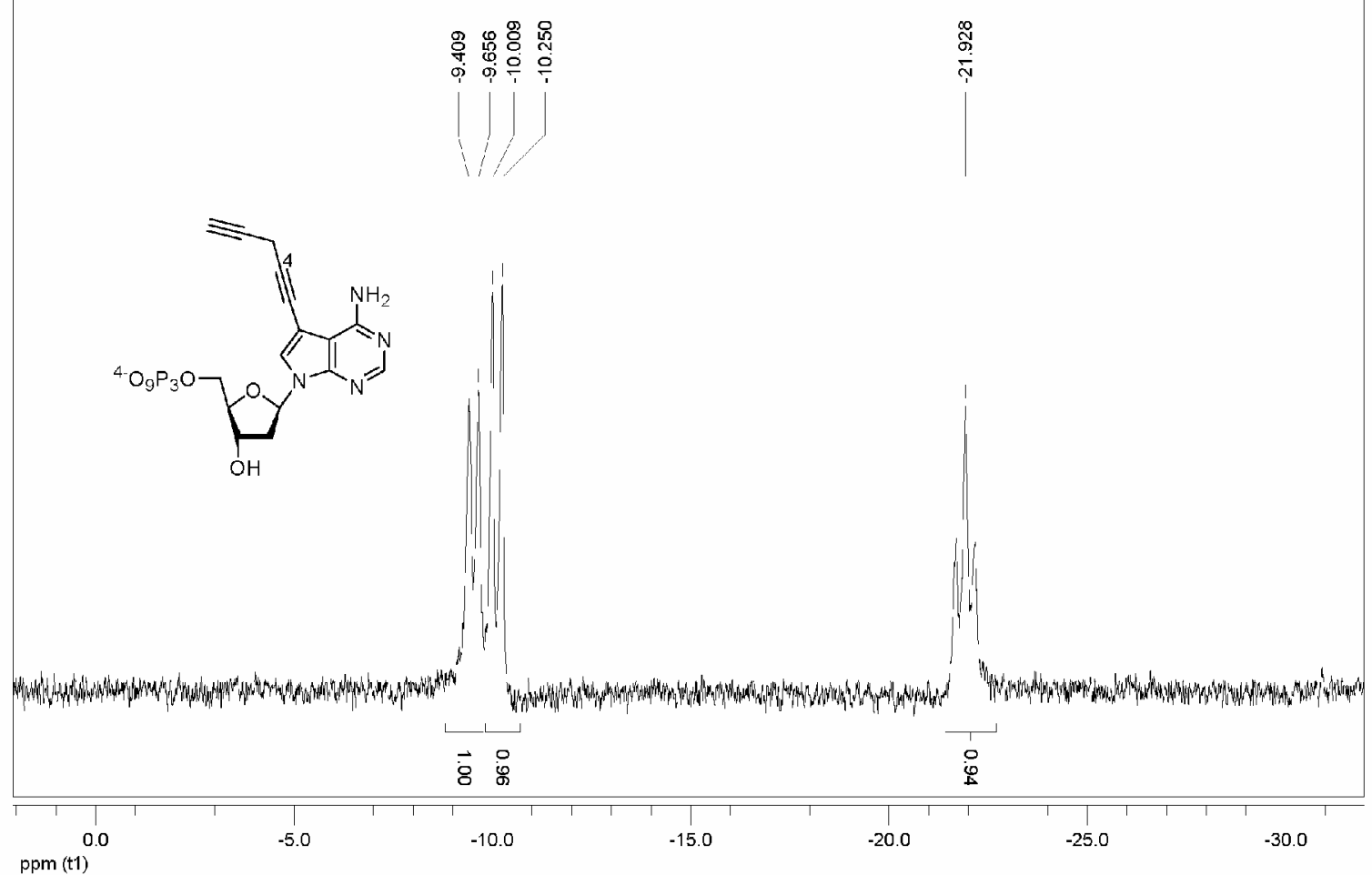

7-Deaza-[7-(7-trimethylsilyl-octa-1,7-diynyl)]-3',5' 0 di-p toluoyl-2'-deoxyguanosine 5

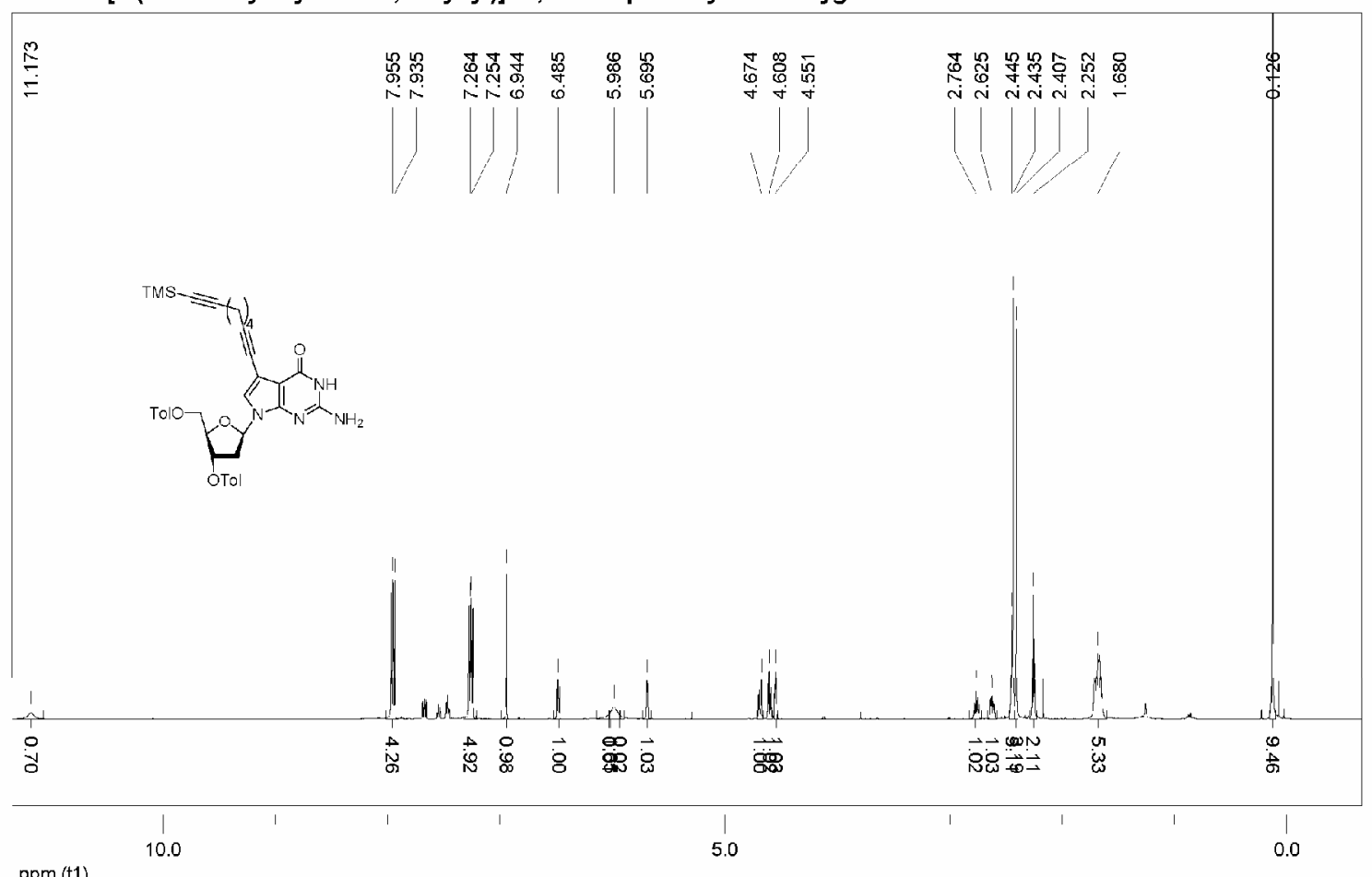


7-Deaza-[7-(7-trimethylsilyl-octa-1,7-diynyl)]-3',5' 0 di-p toluoyl-2'-deoxyguanosine 5

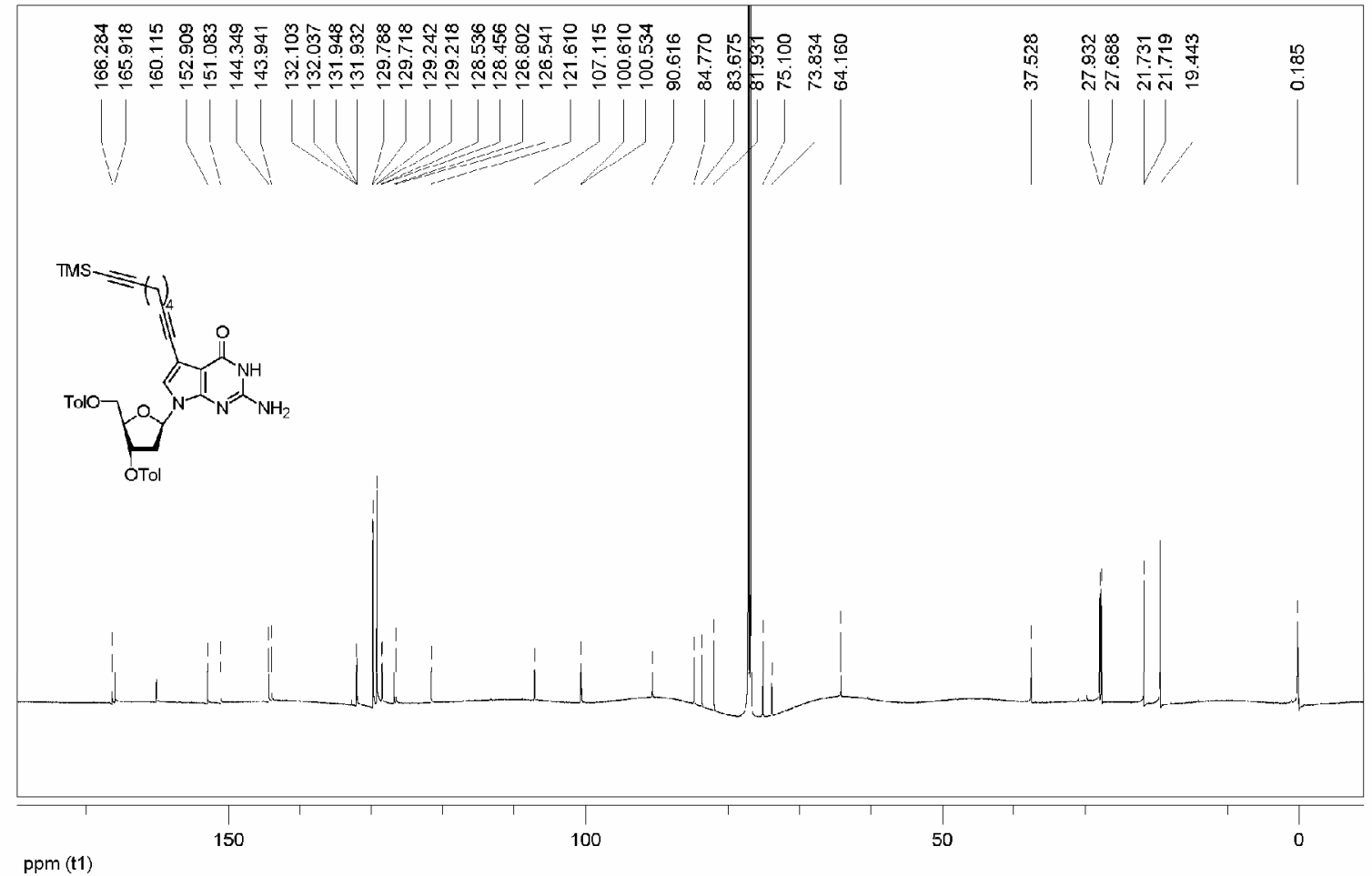

7-Deaza-7-(octa-1,7-diynyl)-2'-deoxyguanosine 6

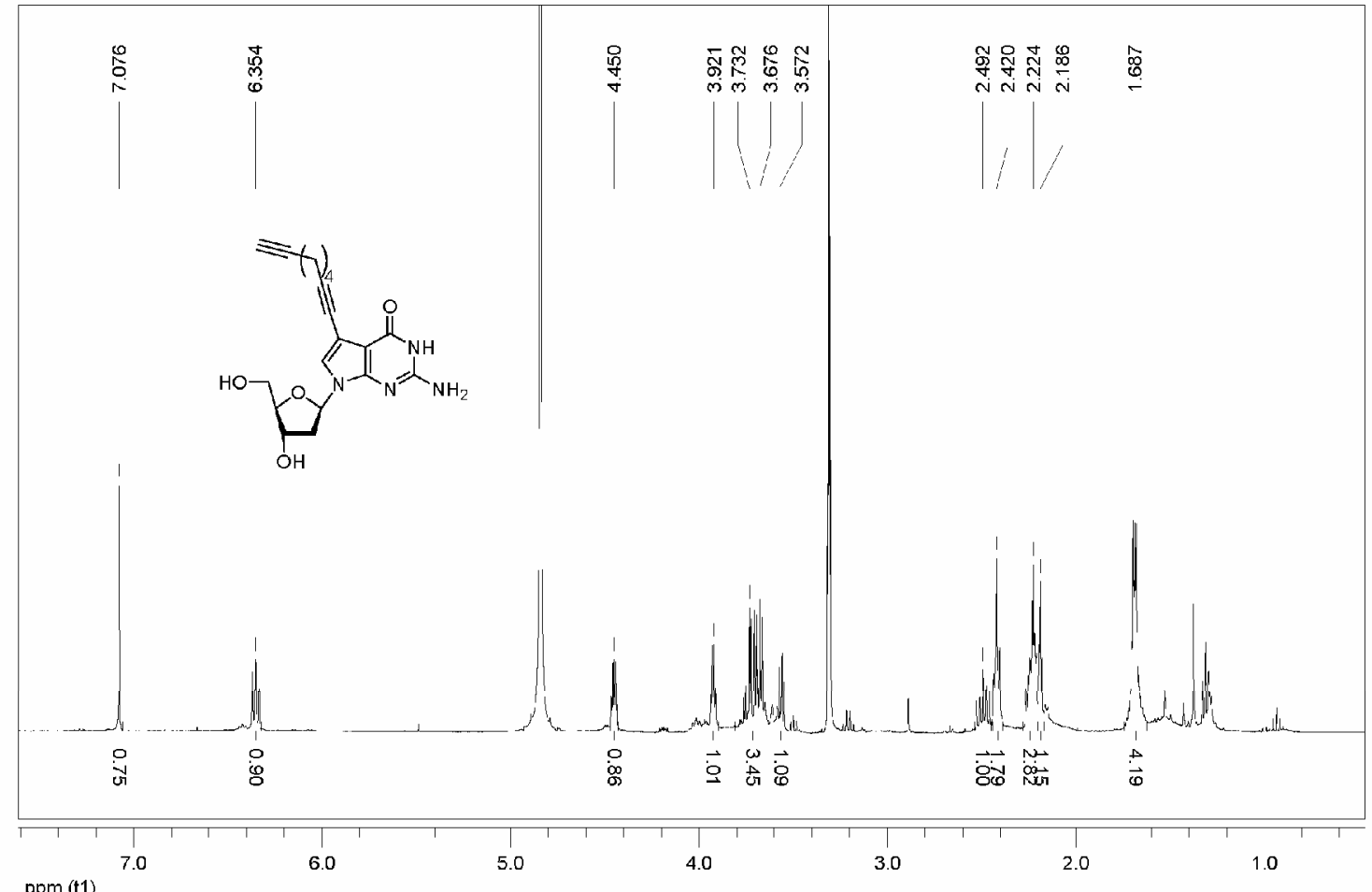


7-Deaza-7-(octa-1,7-diynyl)-2'-deoxyguanosine 6

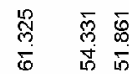

商

$\mid$

$\approx+1$<smiles></smiles>

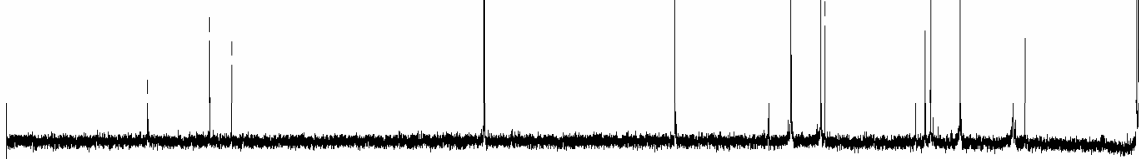

150

100

ppm (t1)

7-Deaza-7-(octa-1,7-diynyl)-2'-deoxyguanosine-5' -0-triphosphate 7

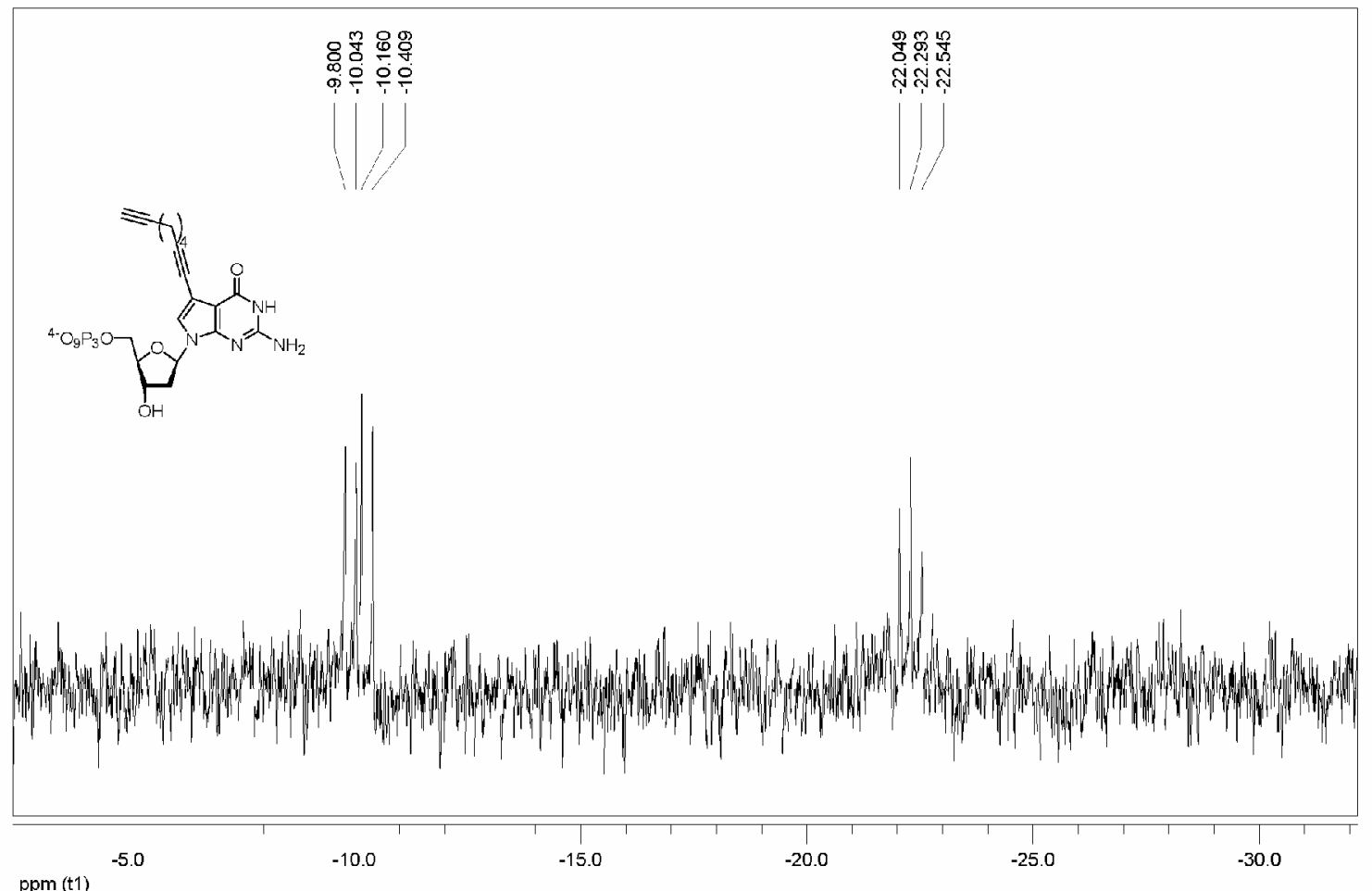


[1] J. Gierlich, K. Gutsmiedl, P. M. E. Gramlich, A. Schmidt, G. Burley, T. Carell, Chem.--Eur. J. 2007, accepted.

[2] C. A. Buhr, R. W. Wagner, D. Grant, B. C. Froehler, Nucleic Acids Res. 1996, 24, 2974.

[3] H. A. Held, S. A. Benner, Nucleic Acids Res. 2002, 30, 3857.

[4] T. R. Chan, R. Hilgraf, K. B. Sharpless, V. V. Fokin, Org. Lett. 2004, 6, 2853. 